\title{
The Implementation of School Literacy Movement in Elementary School
}

\author{
B. Yulianto, F. Jannah \& Nurhidayah \\ Universitas Negeri Surabaya, Surabaya, Indonesia
}

\begin{abstract}
The Launching of School Literacy Movement (SLM) is intended to involve schools, academics, publishers, mass media, and the public in order to support the reading habituation of students. Data were taken in SD Laboratorium Unesa and SDN 21 Ampenan at West Nusa Tenggara. The research involves the implementation of the literacy activities, student literacy activities, school activities in order to support SLM, and supporting and inhibiting factors. Both schools have implemented the program with the relatively similar condition. The process of implementation has not yet carried out literacy associated with curriculum. Supporting factor are the well-utilized school infrastructure, regular literacy training, well-run library management, and monitoring and evaluation of SLM implementation. The inhibition factor is not yet the formation of School Literacy Team and the lack of involvement of parents.
\end{abstract}

Keywords - Literacy Movement; Elementary School;

\section{INTRODUCTION}

PISA report shows the reading ability of Indonesian society in 2006 occupies position 48 of 56 countries in the world. In 2009 the position of Indonesia was at 57 out of 65 countries. In 2012, PISA placed Indonesian students in the second worst position of 64 out of 65 countries. So that one of the efforts of the Ministry of Education is that undermining Indonesia's competitiveness in future global competition. Culture of Indonesia to overcome it is by developing the School Literacy Program which involves all stakeholders in the field of education, from the central, provincial, district / city, to the educational unit as well as the public element, Old, Alumni, community, business and industry (Ministry of Education and Culture 2016: 1).

Surabaya as one of Indonesia big cities has declared itself as the City of Literacy. Its activities cover a service for the Surabaya citizens with Regional Libraries, Library Bus Service, Community Institution (TBM), Revitalization of TBM and Primary School Library. These activities synergize with learning activities at school. School literacy movement is also implemented. Related to that, as for further research that is School Literacy Movement at SD Laboratorium Unesa of Surabaya as one of big city in Indonesia and school literacy movement at SDN 21 Ampenan in NTB as one of small towns in Indonesia. The focus of the study is about student literacy activities, school actions in support of School Literacy Movement, as well as factors that influence it.
The Prague Declaration in 2003 mentioned that literacy is not only about reading and writing, but also about how one communicates within a society (Unesco, 2003). In communicating these people apply the thinking process. This is in line with Suyono's statement (2015: 503) that the essence of literacy is a reading-thinking-writing activity. Literacy also means practices and social relationships related to knowledge, language, and culture (Fauziah, et al., 2016: 7). In this case the ability of literacy can be improved through habituation [6]. In language learning, literacy approach is aimed at preparing students to participate in real life (Hammond in Sodiq, 2010: 88). In Elementary School, the School Literacy Movement is implemented gradually: 1) reading activity stage, 2) development stage of reading interest, and 3) implementation phase of literacy based learning (Anderson \& Krathwol, 2001). The goal of this school literacy movement program is to grow the literacy culture in schools, increase the literacy capacity of citizens and the school environment, make the school a pleasant learning park, and maintain the sustainability of learning, by presenting a variety of reading books and accommodating various reading strategies [10].

\section{METHOD}

This research analyzes the implementation of school literacy movement in SD Laboratorium Unesa and SDN 21 Ampenan in NTB, qualitatively using content analysis technique and descriptive analysis technique. SD Laboratorium Unesa is a Primary School in a big city in the western part of Indonesia, while the SDN 21 Ampenan is a Primary School in a small town, located in eastern Indonesia.

The data was taken through deep observation and interviews with a number of students in both schools. Interviews were also conducted for principals, teachers, librarians, school literacy teams, and school committees. To know the supporting and inhibiting factors.

\section{RESULTS AND DISCUSSION}

a. Student literacy activity

Student literacy activity at SD Laboratorium UNESA is seen based on the stages of the School Literacy Implementation. 


\section{A. Stage habituation}

Student literacy activities at the stage of habituation for the high grade are longer listening to understand the content of reading, comprehending reading content with various strategies, reading books with various strategies (recognizing text types, making inferences, connections with experiences/ other texts, etc.), and reading in the heart. Based on observations at high grade in SD Laboratorium Unesa, most students carry out reading activities in the heart, students do listening activities to understand the contents of reading. Students understand the content of reading by recognizing the type of text and associating it with the student experience.

\section{B. Development stage}

In the development stage of student literacy activity in Elementary School in high grade, it shows that there are some student activities include listening, reading, speaking, writing, and sorting information. Here are the results of observations carried out in the High Grade of SD Laboratorium Unesa.

Based on the observations in the high grade of SD Laboratorium Unesa indicates that students' literacy activities include listening, reading, speaking, writing, and sorting information. Each grade has carried out the activity, but has not implemented all activities. Each grade performs several activities only.

\section{Learning stage}

The results of the research in the high grade of SD Laboratorium Unesa indicate that the stage of implementation of the School Literacy Movement has not been in the learning stage. Based on the results of observations conducted, there is the behavior of reading students in accordance with the stage of learning that students show interest in reading and choose books independently in accordance with his interests with or without guidance. However, other students' literacy activities have not been implemented.

Student literacy activities at SD Laboratorium Unesa are different from student's literacy activity in SDN 21 Ampenan. Literacy activities of learners are activities undertaken by learners during the process of School Literacy Movement progresses. It consists of basic literacy, media literacy, library literacy, technology and visual literacy.

Student literacy activity in SDN 21 Ampenan consists of five forms of literacy among others how students in SDN 21 Ampenan use basic literacy related to the implementation of reading 15 minutes non-learning book before the learning begins. Student activity in applying library literacy implemented in SDN 21 Ampenan learns how to distinguish fiction and nonfiction books available in library, reading corner, or book bag, and how learners search for books according to the book code and the type of book that was accompanied by the library staff. Fig 1 shows the data of student visit based on the results of library personnel assistance:

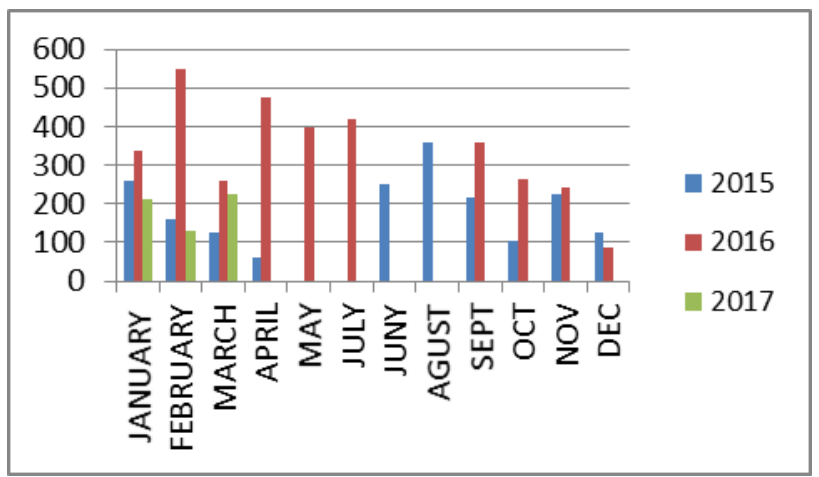

Fig 1. Data of SDN 21 Ampenan West Nusa Tenggara from School Year 2015 Until 2017

In coping with media literacy, students of SDN 21 Ampenan use media used to support classroom learning. In accordance to technological literacy, the students utilize technology and internet provided at by the school for the sake of providing them online services which, in the same time, can help them to hone their skills anytime and anywhere.

Media literacy is typically defined as the ability to access, analyze, evaluate, and produce communication in a various forms. A module named 'Mass Media Analysis and Interpretation' incorporates the practical course of ELT to define media very broadly, including books, newspapers, magazines, videos, movies, recorded music, and everything available via the Internet. Special emphasis, though, is to be put on multimedia [2].

The above explanation suggests that media literacy is usually defined as the ability to access, analyze, evaluate and produce communication in various forms. There is a special emphasis even in multimedia. In visual literacy, oral and written bills as a non-academic assessment of learners are based on the journal responses made by students at school.

According to Aisami (2015:539), this paper aims to address some fundamental questions about learning styles and visual literacy for both learning and performance [1]. The questions include how people learn; what the learning styles, and how it is determined. The journals used suggest to use learning styles and visual literacy for learning and performance.

\section{School activity in support of School Literacy Movement}

In order for the school to be the front line in the development of literary culture, Beers, et al. (Wiedarti, Pangesti \& Laksono, Kisyani (Ed), 2016: 10) provide several strategies to create a positive literacy culture in schools that ininclud [9].

\section{1) Physical environment}

Based on the results of observations conducted in class IV, class V, and class VI at SD Laboratorium Unesa showed that the school has displaying students' work in each class, the work of students rotated periodically to give equal opportunity 
to all students, books and reading materials available in the reading corner in all classes IV, class V, and class VI. The school has provided reading books in each class. There are also books and other reading materials available for students and parents / visitors in the office such as magazines and daily newspapers. It is similar to SDN 21 Ampenan, the school appreciates each student's work by displaying the work of participants in every corner of the classroom and rotated once every week, and the school provides reading material easily in the reading corner of the classroom. Then, reading pocket is available in the classroom and school libraries that provide a variety of reading materials.

\section{2) Social and affective environments}

Observation results from March 6, 2017 to March 30, 2017 at the SD Laboratorium Unesa indicate that there is an appreciation of student achievement at SD Laboratorium Unesa award awarded during the flag ceremony. Students' appreciation is also done in the classroom with the classroom boards. Each student has the same opportunity to become a class star.

The principal is actively involved in the development of literacy. School staff are also involved in the decision-making process, especially running literacy programs. In carrying out literacy, the principal cooperates with librarians and staff of the Library and Filing Service. Implementation of the School Literacy Movement at the UNESA Classroom Laboratory classroom is conducted in class with each classroom teacher and is conducted in a library devoted to developing student literacy. There is a culture of collaboration between teachers and staff by recognizing their respective expertise. This is indicated by the scheduling of literacy activities in libraries that are staffed by Library and Archives staff on the sidelines of the lesson agreed by the classroom teacher. Class teachers allow their students to join literacy activities in the library.

SDN 21 Ampenan appreciates every academic and nonacademic achievement of students, involvement and role of all stakeholders in SDN 21 Ampenan gives a positive impact on the implementation of School Go samba School Literacy Movement. In addition, the SDN 21 Ampenan has a regular schedule for the involvement of teachers and school staff in supporting the implementation of School Go Literacy Movement by coordinating every activity of School Literacy Movement and book review conducted by principals, staff and teachers once a month for increase knowledge.

\section{3) Academic environment}

At SD Laboratorium Unesa there is a special time and enough time for learning and literacy habituation, ie once a week students are given a schedule to visit the library and accompanied by Library Service Officers and Archives who are given the task to provide training on literacy. Literacy time is not to be sacrificed for other purposes, in SD Laboratorium Unesa is agreed upon fifteen minutes before the learning is at 07.00-07.15 WIB. Fiction and nonfiction books are available in sufficient numbers in schools according to data from school libraries.

In SDN 21 Ampenan, all the activities of School Literacy Movement in the assessment by the school to see how far the implementation of School Literacy Movement in SDN 21 Ampenan, among others, coordinate the implementation of the reading 15 minutes before learning begins, visiting the library 20 minutes after break time, completeness Books that students need as well as publish School Literacy activities.

\section{E. Factors Supporting School Literacy Movement}

At SD Laboratorium Unesa, literacy activities can run optimally with collaboration between all elements of government and society. Education Units Have their respective roles. In addition to the role of educational units of teachers and principals, there are also questions for librarians and committees answered by Mr. Jusmono, regarding the librarian's job to inventory books, provide fiction and nonfiction books and create a comfortable reading room, and the procurement of books on a regular basis.

SDN 21 Ampenan meets the national standard of national basic education service in accordance with Permendiknas no. 23 year 2014. Implementing the School Literacy Movement up to the learning stage in the implementation implemenatsi School Literacy Movement at SDN 21 Ampenan in the learning process utilizes school libraries, school gardens, reading corner as a source of learning. The school also manages the library as a learning resource for students already computing standardized to book inventory, serving the borrowing and return of books and counting the most readers every semester and year.

\section{F. Factor Inhibiting School Literacy Movement}

The Education Unit has not performed its role, so it is included in the inhibiting factor. Based on the interview with $\mathrm{Mr}$ jusmono head of SD Laboratorium Unesa there are some things that hinder School Literacy Movement. Based on the results of the interviews, it can be seen that the inhibiting factor of the School Literacy Movement at SD Laboratorium Unesa is that there is no School Literacy Team so that no one carries on the role of School Literacy Team.

SDN 21 Ampenan, based on the findings of the inhibiting factors of the Literacy Movement of Go Samba School is to require students to read a number of literary books because of the lack of awareness of parents to give examples to their children to diligently read, have a high interest in collecting books, Books, providing reading books for their children, providing time for reading and discussion together, bringing their children to visit libraries and bookstores, conduct activities together with schools or community groups in literacy activities, and so on. 
All school activities involving parents are very difficult to do in SDN 21 Ampenan because the background of uneducated parents, and lack of awareness of parents to education.

\section{CONCLUSION}

In the process of implementing School Literacy Movement (SLM), the school preparation phase has been implemented. In school literacy activities, SD Laboratorium Unesa is in the development stage while SD Ampenan 21 is at the learning stage. There are different obstacles and supporters in the implementation of the School Literacy Movement.

\section{REFERENCES}

[1] R.S. Aisami, Learning styles and visual literacy for learning and performance, Procedia-Social and Behavioral Sciences, 176: 538-545, 2015.

[2] O.S. Dvorghets, and Y.A. Shaturnaya, Developing students' media literacy in the English language teaching context, Social and Behavioral Sciences, 200: 192-198, 2015.

[3] Peraturan Menteri Pendidikan Nasional Tahun 2006 Nomor 22.

[4] Peraturan Menteri Pendidikan dan Kebudayaan Nomor 23 Tahun 2015.

[5] S. Sodiq, Pengembangan materi pendidikan kecakapan hidup pada buku pelajaran Bahasa Indonesia dengan model literasi, Disertasi: Universitas Negeri Surabaya, 2010.

[6] H. Subandiyah, Pembelajaran literasi dalam mata pelajaran Bahasa Indonesia, Universitas Negeri Surabaya, 2016.

[7] Suyono, Pembelajaran efektif dan produktif berbasis literasi: Analisis konteks, prinsip, dan wujud alternatif strategi implementasinya di sekolah, Sastra Indonesia Fakultas Sastra Universitas Negeri Malang, 2015.

[8] Wiedarti, Pangesti \& K. Laksono, (Ed). Desain induk gerakan literasi sekolah, Jakarta: Direktorat Jenderal dan Menengah Kementerian Pendidikan dan Kebudayaan, 2016.

[9] Wiedarti, Pangesti \& Laksono, Kisyani (Ed), Panduan Gerakan Literasi Sekolah di Sekolah Dasar, Jakarta: Direktorat Jenderal dan Menengah Kementerian Pendidikan dan Kebudayaan, 2016.

[10] D.U. Faizah, Panduan gerakan literasi sekolah di sekolah dasar, Jakarta: Direktorat Jenderal dan Menengah Kementerian Pendidikan dan Kebudayaan, 2016. 